\title{
Usulan Penjadwalan Perawatan Mesin Menggunakan Metode Reliability Block Diagram
}

\author{
Evi Febianti*1, Putro Ferro Ferdinant ${ }^{2}$, Nuraida Wahyuni ${ }^{3}$ dan Desy Nur Riyani ${ }^{4}$ \\ ${ }^{1}$ Jurusan Teknik Industri, Fakultas Teknik, Universitas Sultan Ageng Tirtayasa, \\ Jln. Jend Sudirman KM.03, Cilegon, Banten, 42435 \\ Email: evi@untirta.ac.id ${ }^{1}$,ferdinant@untirta.ac.id² ${ }^{2}$,nrdwahyuni@gmail.com ${ }^{3}$, desynurriyani@yahoo.co.id
}

DOI: 10.20961/performa.19.1.40983

\begin{abstract}
Abstrak
PT. XYZ merupakan perusahaan yang bergerak pada bidang manufaktur dengan hasil produknya adalah baja. Kegiatan perawatan memegang peranan penting. Perusahaan perlu melakukan penjadwalan perawatan mesin secara teratur. Penelitian ini berfokus pada unit produksi CTCM (Continuous Tandem Cold Mill) yang memiliki breakdown time yang tinggi. Adapun tujuan penelitian adalah menentukan pola kerusakan dan nilai MTBF (mean time between failure), menghitung nilai reliabilitas dan availabilitas dengan corrective maintenance, menentukan waktu preventive maintenance dan reliabilitas sistem berdasarkan reliability block diagram, serta menentukan availabilitas setelah dilakukan preventive maintenance. Metode yang digunakan dalam penelitian ini adalah reliability block diagram (RBD). Hasil perhitungan menunjukkan semakin kecil nilai MTBF dari suatu mesin, maka frekuensi kerusakan semakin banyak pada mesin tersebut. Semakin besar nilai reliabilitas mesin maka semakin besar nilai availabilitasnya. Semakin banyak frekuensi kerusakan yang dialami mesin maka diperlukan perawatan mesin yang rutin. Nilai reliabilitas setiap mesin yang meningkat mempengaruhi persentase reliabiltas sistem. Dibandingkan dengan corrective maintenance, jadwal preventive maintenance yang diusulkan meningkatkan nilai availabilitas mesin sebesar 21,18\%.
\end{abstract}

Kata kunci: Corrective Maintenance, Preventive Maintenance, Reliabilitas, Reliability Block Diagram

\begin{abstract}
PT. XYZ is a company engaged in manufacturing with the result of its products is steel. Maintenance activities play an important role. The company needs to conduct regular machine maintenance scheduling. This research focuses on CTCM (Continuous Tandem Cold Mill) production units that have a high breakdown time. The objectives of the study are to determine the pattern of damage and the value of MTBF (mean time between failure), calculate the value of reliability and availability with corrective maintenance, determine the time of preventive maintenance and system reliability based on the reliability block diagram, and determine availability after preventive maintenance. The method used in this study is the reliability block diagram (RBD). The calculation results show that the smaller the MTBF value of an engine then the more frequency of damage. The greater the reliability value of the machine, the greater the value of availability. The more frequency of damage experienced by the machine, the routine maintenance of the machine is required. The increased reliability value affects the percentage of system reliability. Compared to corrective maintenance, the proposed preventive maintenance schedule increases the value of engine availability by $21.18 \%$.
\end{abstract}

Keywords: Corrective Maintenance, Preventive Maintenance, Reliabilitas, Reliability Block Diagram

\section{Pendahuluan}

Kegiatan perawatan memegang peranan penting dalam perusahaan. Tanpa adanya kegiatan perawatan yang sesuai, pihak perusahaan akan mengalami kerugian besar seperti mesin rusak dan tidak dapat berfungsi kembali, jumlah produk cacat meningkat, hingga kerugian material akibat seringnya mengganti komponen pada mesin. Perawatan mesin yang baik dapat memperbaiki dan menjaga kehandalan mesin. Kendala utama dalam aktivitas perawatan mesin adalah menentukan waktu penjadwalan perawatan mesin secara teratur (Priyanta, 2000).

PT. XYZ adalah perusahaan manufaktur penghasil baja. Dengan salah satu anak perusahaan nya adalah Pabrik Cold Rolling Mill (CRM). Strategi bisnis yang diterapkan oleh PT. XYZ adalah make to order, pabrik CRM memproduksi baja lembaran dingin sesuai dengan spesifikasi dari pelanggan. Proses reduksi ketebalan adalah proses utama pada pabrik CRM karena parameter ketebalan merupakan jenis spesifikasi dari konsumen selain jenis baja. Proses reduksi ketebalan strip baja adalah proses yang terjadi di unit produksi Continuous Tandem Cold Mill (CTCM) saat strip baja melalui proses tarik dan tekan dengan

\footnotetext{
* Penulis utama (Corresponding author)
} 
perlakuan dingin hingga ketebalan dapat tereduksi sebanyak 92\% dari ketebalan awal. Sebagai unit produksi yang penting, unit produksi CTCM memiliki breakdown time yang tinggi dibandingkan dengan unit produksi lainnya.

Berdasarkan data dari perusahaan, tingginya breakdown yang terjadi pada unit produksi CTCM menyebabkan terjadinya idle pada unit produksi ECL. Idle pada unit produksi ECL dikarenakan tidak adanya supply bahan baku baja dari unit produksi CTCM. Breakdown pada setiap mesin di unit produksi CTCM tersebut diatasi dengan corrective maintenance dengan kegiatan pemeliharaan dan perawatan yang dilakukan setelah terjadinya suatu kerusakan pada peralatan sehingga peralatan tidak dapat berfungsi dengan baik. Kegiatan corrective maintenance tersebut menyebabkan terganggunya proses produksi baja lembaran dingin di unit produksi CTCM. Untuk mengatasi downtime akibat corrective maintenance, dibutuhkan penjadwalan perawatan secara berkala. Penjadwalan perawatan ini disebut dengan preventive maintenance. Reliability block diagram adalah metode untuk menganalisa kehandalan sistem pada sistem besar dan kompleks dengan menggunakan diagram blok sistem (Ebeling, 1997). Reliability block diagram ini menggunakan data waktu antar kerusakan dari mesin-mesin di unit produksi CTCM. Data waktu tersebut digunakan untuk mencari pola distribusi yang sesuai dengan pola kerusakan masing-masing mesin. Parameter distribusi digunakan untuk mencari nilai waktu rata-rata antar kerusakan (MTBF) dan nilai reliability masing-masing mesin. Selanjutnya menghitung nilai reliabity sistem mesin di unit produksi CTCM dan menentukan jadwal preventive maintenance (Nuhman, 2016). Kemudian dilakukan perhitungan availability untuk mengetahui apakah kegiatan preventive maintenance mengurangi availabilitas mesin dibandingkan dengan corrective maintenance (Ebeling 1997).

Adapun tujuannya pada penelitian adalah menentukan pola kerusakan dan nilai MTBF (mean time between failure) setiap mesin, menghitung nilai reliabilitas dan availabilitas setiap mesin dengan corrective maintenance, menentukan waktu preventive maintenance setiap mesin dan reliabilitas sistem berdasarkan reliability block diagram dan menentukan availabilitas setiap mesin setelah dilakukan preventive maintenance. Penelitian yang berkaitan adalah penelitian Kudin (2012) yang membahas mengenai nilai reliabilitas sistem komponen listrik pada unit stand 3 dengan reliability block diagram. Untuk mencapai reliabilitas sistem sebesar $85 \%$ bagian perawatan menjadwalkan 9 komponen listrik pada unit stand 3 dengan memperbaiki jadwal perawatan sehingga mencapai reliabilitas masing - masing komponen sebesar 95\%. Penelitian lainnya yang berkaitan adalah Saputro (2013) yang membahas mengenai nilai reliabilitas sistem mesin SPM 2000 dengan reliability block diagram dan model simulasi diskrit untuk mengetahui utilitas mesin. Penelitian tersebut menggunakan preventive maintainance untuk meningkatkan reliabilitas sistem sebesar $85 \%$ dan penjadwalan perawatan terencana, pengarahan kepada para operator dan melakukan pengawasan untuk meningkatkan utilitas. Kulsum (2018) melakukan penjadwalan preventive maintenance pada mesin paper mill 1 untuk menurunkan waktu downtime dengan menggunakan simulasi monte carlo. Perbedaan penelitian terdahulu dengan penelitian ini terletak pada kasus, data dan objek serta penelitian ini memberikan usulan waktu preventive maintenance setiap mesin dan reliabilitas sistem berdasarkan reliability block diagram dan menentukan availabilitas setiap mesin setelah dilakukan preventive maintenance.

\section{Metode Penelitian}

Data primer pada penelitian ini diperoleh dengan cara melakukan wawancara terhadap pihak yang dapat memberikan informasi terkait maintenance di unit produksi CTCM. Teknik wawancara yang digunakan berupa garis besar permasalahan yang sedang terjadi. Selain itu, dilakukan observasi langsung di unit produksi CTCM. Sedangkan data sekunder adalah data yang dapat diperoleh peneliti tanpa melakukan observasi langsung di lapangan. Data sekunder ini berupa data perusahaan dan data historis di unit produksi CTCM.

Data yang dibutuhkan dalam penelitian ini adalah data umum perusahaan dan data waktu kerusakan mesin di unit produksi CTCM. Dari data waktu yang diperoleh kemudian dilakukan pengolahan data dengan mengelompokan waktu kejadian pada setiap mesin, kemudian dari data tersebut dihitung waktu antar kerusakan (TBF). Dari data waktu antar kerusakan kemudian menghitung index of fit untuk identifikasi awal pola distribusi data waktu antar kerusakan. Setelah diketahui pola distribusinya, kemudian dilakukan perhitungan parameter. Dengan parameter yang didapat tersebut kemudian melakukan perhitungan untuk mengetahui waktu rata-rata antar kerusakan (MTBF) dan mengetahui reliabilitas serta laju kerusakan setiap mesin. kemudian dari nilai reliabilitas setiap mesin dilakukan perhitungan reliabilitas sistem dengan 
reliability block diagram (RBD), block diagram yang disusun berdasarkan hubungan setiap mesin pada unit produksi CTCM. Kemudian menentukan interval waktu perawatan dan menghitung availability kondisi awal dan usulan yang diharapkan mampu memperbaiki keandalan mesin di unit produksi CTCM (Larasati, 2017). Berikut adalah Flow chart pemecahan masalah tersaji pada Gambar 1.

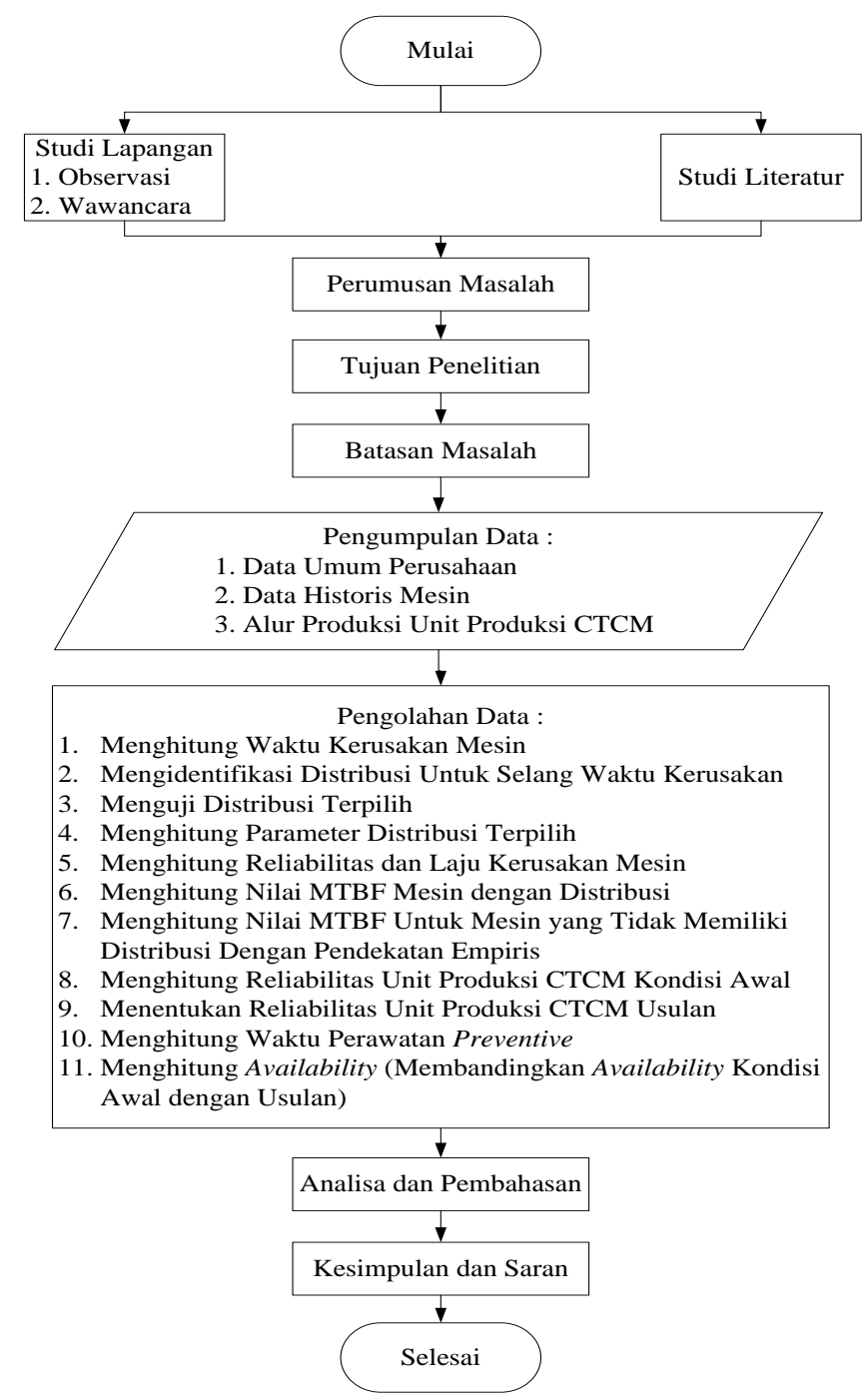

Gambar 1. Flow chart Pemecahan Masalah

\section{Hasil dan Pembahasan}

Pengolahan data pada penelitian ini terdiri dari perhitungan waktu kerusakan, identifikasi distribusi untuk selang waktu kerusakan, perhitungan parameter distribusi, perhitungan reliabilitas dan laju kerusakan, perhitungan MTBF, reliability block diagram, usulan jadwal preventive maintenance dan availability.

\subsection{Perhitungan Waktu Antar Kerusakan Mesin}

Berikut ini adalah contoh perhitungan waktu kerusakan mesin uncoiler :

a. Mesin uncoiler mengalami kerusakan pertama dan kedua, dengan selisih hari sebanyak 18 hari atau sama dengan 18 hari x 24 jam adalah 432 jam.

b. Kerusakan kedua terjadi pada pukul 7:40 adalah setelah pukul 3:13, artinya kerusakan selanjutnya terjadi setelah 18 hari. Selisih waktu antara jam 3:13 sampai 7:40 adalah 267 menit. Dengan begitu TTF sebesar $(432$ x 60 menit $)+267$ menit $=26187$ menit.

c. TTR = actual completion - actual start

$$
\begin{aligned}
& =3: 13-2: 28 \\
& =45 \text { menit }
\end{aligned}
$$

d. $\mathrm{TBF}=\mathrm{TTF}+\mathrm{TTR}$

$$
\begin{aligned}
& =26187+45 \\
& =26.232 \text { menit }
\end{aligned}
$$


Tabel 1. Perhitungan Time Between Failure Mesin Uncoiler

\begin{tabular}{cccccc} 
& & & \multicolumn{2}{c}{ Waktu Terjadi } & \\
No & Workstation & Mesin & \multicolumn{2}{c}{ Kerusakan } & Kerusakan \\
\cline { 3 - 4 } & & & Mulai & Akhir & (menit) \\
\cline { 3 - 4 } 1 & Entry & Uncoiler & $2: 28$ & $17: 53$ & 68 \\
2 & Entry & Uncoiler & $7: 40$ & $22: 46$ & 33 \\
3 & Entry & Uncoiler & $14: 00$ & $9: 45$ & 17 \\
4 & Entry & Uncoiler & $19: 00$ & $14: 21$ & 10 \\
5 & Entry & Uncoiler & $22: 00$ & $3: 52$ & 19 \\
6 & Entry & Uncoiler & $6: 00$ & $11: 15$ & 35 \\
7 & Entry & Uncoiler & $14: 00$ & $2: 49$ & 95 \\
8 & Entry & Uncoiler & $22: 40$ & $3: 16$ & 17 \\
9 & Entry & Uncoiler & $0: 35$ & $18: 12$ & 77 \\
10 & Entry & Uncoiler & $6: 00$ & $19: 50$ & 11 \\
11 & Entry & Uncoiler & $10: 15$ & $4: 35$ & 15 \\
12 & Entry & Uncoiler & $11: 00$ & $19: 21$ & 50 \\
13 & Entry & Uncoiler & $14: 00$ & $0: 27$ & 41 \\
14 & Entry & Uncoiler & $20: 06$ & $23: 32$ & 9 \\
15 & Entry & Uncoiler & $14: 00$ & $9: 00$ & 43 \\
16 & Entry & Uncoiler & $6: 00$ & $14: 00$ & 208 \\
17 & Entry & Uncoiler & $6: 50$ & $14: 25$ & 25 \\
18 & Entry & Uncoiler & $9: 10$ & $3: 10$ & 225 \\
19 & Entry & Uncoiler & $23: 19$ & $15: 40$ & 70 \\
20 & Entry & Uncoiler & $12: 00$ & $10: 02$ & 44 \\
21 & Entry & Uncoiler & $14: 00$ & $11: 37$ & 45 \\
22 & Entry & Uncoiler & $4: 18$ & $14: 35$ & 15 \\
23 & Entry & Uncoiler & $14: 00$ & $20: 15$ & 15 \\
24 & Entry & Uncoiler & $18: 00$ & $8: 54$ & 54 \\
25 & Entry & Uncoiler & $17: 05$ & $1: 29$ & 12 \\
26 & Entry & Uncoiler & $6: 00$ & $11: 05$ & 75 \\
27 & Entry & Uncoiler & $17: 31$ & $3: 00$ & 60 \\
28 & Entry & Uncoiler & $6: 00$ & $4: 00$ & 10 \\
29 & Entry & Uncoiler & $7: 20$ & $16: 50$ & 70 \\
30 & Entry & Uncoiler & $14: 21$ & $17: 35$ & 15 \\
31 & Entry & Uncoiler & $21: 30$ & $0: 55$ & 77 \\
32 & Entry & Uncoiler & $20: 00$ & $6: 00$ & 470 \\
\hline & & & & &
\end{tabular}

\subsection{Index Of Fit}

Pada tahap ini dilakukan perhitungan index of fit estimasi awal mengenai parameter dari masing-masing distribusi. Pada mesin yang memiliki kerusakan $\leq 3$ (mesin crop shear dan strip flattener) tidak dilakukan pengujian dengan distribusi melainkan dengan pendekatan empiris yang akan dihitung pada sub bab selanjutnya. Selain menggunakan perhitungan manual, dilakukan penentuan besaran index of fit dengan menggunakan software minitab untuk membandingkan perhitungan manual dengan perhitungan software tersaji pada Tabel 2.

Tabel 2. Rekapitulasi Index of Fit

\begin{tabular}{l|cc|cc|cc|cc}
\hline \multirow{2}{*}{ Mesin } & \multicolumn{2}{c}{$\begin{array}{c}\text { Distribusi } \\
\text { Normal }\end{array}$} & \multicolumn{2}{c}{$\begin{array}{c}\text { Distribusi } \\
\text { Eksponensial }\end{array}$} & \multicolumn{2}{c}{$\begin{array}{c}\text { Distribusi } \\
\text { Weibull }\end{array}$} & \multicolumn{2}{c}{$\begin{array}{c}\text { Distribusi Log } \\
\text { Normal }\end{array}$} \\
\cline { 2 - 9 } & Manual & Minitab & \multicolumn{1}{c}{ Manual } & Minitab & Manual & Minitab & Manual & Minitab \\
\hline Crop & & & & & & & & \\
shear & & & & & & & & \\
Looper & 0,884 & 0,884 & 0,974 & $*$ & 0,964 & 0,964 & 0,971 & 0,971 \\
Pinch roll & 0,950 & 0,95 & 0,956 & $*$ & 0,952 & 0,952 & 0,922 & 0,922 \\
Shear & & & & & & & & \\
back & 0,935 & 0,935 & 0,988 & $*$ & 0,945 & 0,945 & 0,906 & 0,906 \\
pinch roll & & & & & & & & \\
Strip & & & & & & & & \\
flattener & & & & & & & & \\
Trimmer & 0,736 & 0,736 & 0,889 & $*$ & 0,984 & 0,984 & 0,985 & 0,985 \\
Uncoiler & 0,846 & 0,846 & 0,976 & $*$ & 0,950 & 0,950 & 0,973 & 0,973 \\
Welder & 0,902 & 0,902 & 0,964 & $*$ & 0,988 & 0,988 & 0,974 & 0,974 \\
Stand\#1 & 0,870 & 0,870 & 0,984 & $*$ & 0,995 & 0,995 & 0,978 & 0,978 \\
Stand\#2 & 0,872 & 0,967 & 0,829 & $*$ & 0,953 & 0,972 & 0,884 & 0,910 \\
Stand\#3 & 0,837 & 0,837 & 0,958 & $*$ & 0,959 & 0,959 & 0,908 & 0,908 \\
\hline
\end{tabular}


Tabel 2. Rekapitulasi Index of Fit (lanjutan)

\begin{tabular}{l|cc|cc|ccccc}
\hline \multirow{2}{*}{ Mesin } & \multicolumn{2}{c}{$\begin{array}{c}\text { Distribusi } \\
\text { Normal }\end{array}$} & \multicolumn{2}{c}{$\begin{array}{c}\text { Distribusi } \\
\text { Eksponensial }\end{array}$} & \multicolumn{2}{c}{$\begin{array}{c}\text { Distribusi } \\
\text { Weibull }\end{array}$} & \multicolumn{2}{c}{$\begin{array}{c}\text { Distribusi Log } \\
\text { Normal }\end{array}$} \\
\cline { 2 - 10 } & Manual & Minitab & Manual & \multicolumn{1}{c}{ Minitab } & Manual & Minitab & Manual & Minitab \\
\hline Stand\#4 & 0,928 & 0,928 & 0,987 & $*$ & 0,980 & 0,980 & 0,929 & 0,929 \\
Stand\#5 & 0,784 & 0,784 & 0,956 & $*$ & 0,989 & 0,989 & 0,988 & 0,988 \\
Recoiler & 0,854 & 0,854 & 0,982 & $*$ & 0,991 & 0,991 & 0,981 & 0,981 \\
Flying & 0,977 & 0,977 & 0,924 & $*$ & 0,949 & 0,949 & 0,920 & 0,920 \\
shear & & & & & & & & &
\end{tabular}

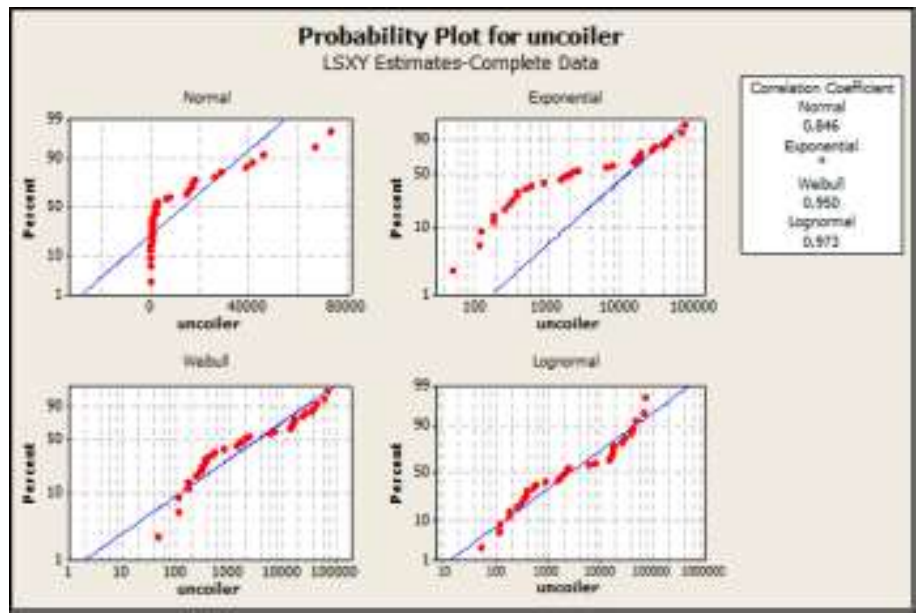

Gambar 2. Index of Fit Mesin Uncoiler dengan Software Minitab

Dari Gambar 2 terlihat nilai koefisien korelasi untuk distribusi normal sebesar 0,846, distribusi weibull sebesar 0,950 dan distribusi log normal sebesar 0,973. Hasil index of fit pada software minitab dan perhitungan manual tidak berbeda signifikan, artinya perhitungan manual dengan software sesuai.

\subsection{Uji Anderson Darling}

Setelah memperoleh index of fit dari setiap distribusi untuk masing-masing mesin, kemudian dilakukan perhitungan nilai anderson darling dan p-value dari setiap distribusi.

Tabel 3. Rekapitulasi Uji Anderson Darling Manual

\begin{tabular}{|c|c|c|c|c|c|c|c|c|}
\hline \multirow{2}{*}{ Mesin } & \multicolumn{2}{|c|}{$\begin{array}{c}\text { Distribusi } \\
\text { Normal } \\
\end{array}$} & \multicolumn{2}{|c|}{$\begin{array}{c}\text { Distribusi } \\
\text { Eksponensial }\end{array}$} & \multicolumn{2}{|c|}{$\begin{array}{c}\text { Distribusi } \\
\text { Weibull }\end{array}$} & \multicolumn{2}{|c|}{$\begin{array}{c}\text { Distribusi Log } \\
\text { Normal }\end{array}$} \\
\hline & AD & $\begin{array}{c}\text { P- } \\
\text { Value }\end{array}$ & AD & $\begin{array}{c}\text { P- } \\
\text { Value }\end{array}$ & AD & $\begin{array}{c}\text { P- } \\
\text { Value }\end{array}$ & AD & $\begin{array}{c}\text { P- } \\
\text { Value }\end{array}$ \\
\hline Looper & 1,214 & 0,002 & 3,895 & $<0.005$ & 0,293 & 0,472 & 0,390 & 0,329 \\
\hline $\begin{array}{l}\text { Pinch } \\
\text { roll }\end{array}$ & 0,376 & 0,282 & 1,875 & $<0.005$ & 0,430 & 0,228 & 0,523 & 0,106 \\
\hline $\begin{array}{l}\text { Shear } \\
\text { back } \\
\text { pinch } \\
\text { roll }\end{array}$ & 0,38 & 0,231 & 0 , & 0,008 & 0,397 & 0,269 & 0,474 & 0,126 \\
\hline Trimmer & 2,041 & $<0.005$ & 4,724 & $<0.005$ & 0,206 & 0,656 & 0,240 & 0,717 \\
\hline Uncoiler & 3,496 & $<0.005$ & 15,075 & $<0.005$ & 0,906 & 0,017 & 0,810 & 0,032 \\
\hline Welder & 2,869 & $<0.005$ & 3,048 & $<0.005$ & 0,428 & 0,256 & 0,627 & 0,095 \\
\hline Stand\#1 & 6,622 & $<0.005$ & 6,223 & $<0.005$ & 0,253 & 0,572 & 0,838 & 0,029 \\
\hline Stand\#2 & 1,287 & 0,002 & 3,139 & $<0.005$ & 5,444 & $<0.005$ & 5,121 & $<0.005$ \\
\hline Stand\#3 & 2,544 & $<0.005$ & 1,203 & $<0.005$ & 1,030 & 0,009 & 1,776 & $<0.005$ \\
\hline Stand\#4 & 1,873 & $<0.005$ & 1,128 & $<0.005$ & 0,798 & 0,033 & 1,940 & $<0.005$ \\
\hline Stand\#5 & 16,326 & $<0.005$ & 24,767 & $<0.005$ & 0,536 & 0,150 & 1,096 & 0,007 \\
\hline Recoiler & 7,582 & $<0.005$ & 11,820 & $<0.005$ & 0,316 & 0,446 & 0,884 & 0,023 \\
\hline $\begin{array}{l}\text { Flying } \\
\text { shear }\end{array}$ & 0,240 & 0,450 & 0,341 & 0,263 & 0,349 & 0,332 & 0,367 & 0,156 \\
\hline
\end{tabular}


Selain menggunakan perhitungan manual, dilakukan penentuan besaran nilai anderson darling dan p-value dengan menggunakan software minitab untuk membandingkan perhitungan manual dengan perhitungan software. Berikut adalah hasil anderson darling mesin uncoiler menggunakan software minitab tersaji pada Gambar 3 :

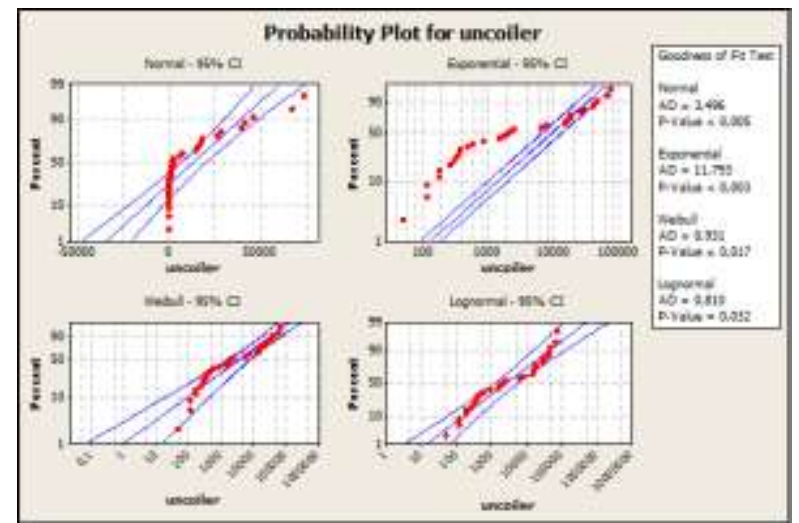

Gambar 3. Anderson Darling Mesin Uncoiler dengan Software Minitab

Dari gambar didapat nilai anderson darling untuk distribusi normal sebesar 3,496 dan p-value <0,005, distribusi eksponensial sebesar 11,793 dan p-value <0,003, distribusi weibull sebesar 0,931dan p-value sebesar 0,017, distribusi log normal sebesar 0,810 dan p-value sebesar 0,032. Hasil index of fit pada software minitab dan perhitungan manual tidak berbeda signifikan, artinya perhitungan manual dengan software sesuai.

\subsection{Uji Goodness of Fit}

Setelah memperoleh index of fit dan nilai anderson darling setiap distribusi untuk masing-masing mesin, dilakukan pengujian kesesuaian terlebih dahulu dan tersaji pada Tabel 4.

Tabel 4. Keputusan Distribusi Untuk Setiap Mesin

\begin{tabular}{lclccc}
\hline \multicolumn{1}{c}{ Mesin } & $\begin{array}{c}\text { Distribusi } \\
\text { Awal }\end{array}$ & Hasil & $\begin{array}{c}\text { Distribusi } \\
\text { Selanjutnya }\end{array}$ & Hasil & Keputusan \\
\hline Looper & Log Normal & Ditolak & Weibull & Diterima & Weibull \\
Pinch roll & Weibull & Diterima & & & Weibull \\
Shear back & Weibull & Diterima & & & Weibull \\
pinch roll & Log Normal & Ditolak & Weibull & Diterima & Weibull \\
Trimmer & Log Normal & Ditolak & Weibull & Diterima & Weibull \\
Uncoiler & Weibull & Diterima & & & Weibull \\
Welder & Weibull & Diterima & & & Weibull \\
Stand\#1 & Weibull & Ditolak & & & Weibull \\
Stand\#2 & Weibull & Diterima & & & Weibull \\
Stand\#3 & Weibull & Diterima & & & Weibull \\
Stand\#4 & Weibull & Diterima & & & Weibull \\
Stand\#5 & Weibull & Diterima & & & Weibull \\
Recoiler & Normal & Diterima & & & Normal \\
Flying shear & Noima
\end{tabular}

\subsection{Perhitungan Parameter Distribusi}

Setelah diketahui pola distribusi kejadian kerusakan yang sesuai untuk masing-masing komponen maka selanjutnya dapat dihitung parameter-parameter distribusi kerusakan sesuai dengan pola distribusinya masing-masing komponen (Nuhman, 2016). Dengan $\beta$ dan $\theta$ sebagai parameter untuk distribusi weibull, serta $\mu$ dan $\sigma$ untuk disrtibusi normal, tersaji pada Tabel 5. 
Tabel 5. Parameter Distribusi Weibull

\begin{tabular}{lcccc}
\hline \multirow{2}{*}{ Mesin } & Distribusi & \multicolumn{3}{c}{ Parameter Distribusi } \\
\cline { 3 - 5 } & & $\boldsymbol{\beta}$ & $\boldsymbol{\alpha}$ & $\boldsymbol{\theta}$ (menit) \\
\hline Looper & Weibull & 0,519 & $-5,204$ & $22.850,961$ \\
Pinch roll & Weibull & 0,357 & $-3,841$ & $47.009,382$ \\
Shear back & Weibull & 0,392 & $-4,293$ & $57.604,040$ \\
pinch roll & & & \\
Trimmer & Weibull & 0,598 & $-5,747$ & $14.910,225$ \\
Uncoiler & Weibull & 0,513 & $-4,574$ & $7.458,968$ \\
Welder & Weibull & 0,706 & $-6,535$ & $10.447,718$ \\
Stand\#1 & Weibull & 0,740 & $-6,164$ & $4.136,809$ \\
Stand\#2 & Weibull & 0,722 & $-6,800$ & $12.276,830$ \\
Stand\#3 & Weibull & 0,683 & $-6,455$ & $12.717,570$ \\
Stand\#4 & Weibull & 0,647 & $-5,968$ & $10.097,539$ \\
Stand\#5 & Weibull & 0,732 & $-5,644$ & $2.237,175$ \\
Recoiler & Weibull & 0,663 & $-5,534$ & $4.194,740$ \\
\hline
\end{tabular}

Tabel 6. Parameter Distribusi Normal

\begin{tabular}{|c|c|c|c|}
\hline \multirow{2}{*}{ Mesin } & \multirow{2}{*}{ Distribusi } & \multicolumn{2}{|c|}{$\begin{array}{c}\text { Parameter } \\
\text { Distrbusi }\end{array}$} \\
\hline & & $\begin{array}{c}\boldsymbol{\mu} \\
\text { (menit) }\end{array}$ & $\sigma$ \\
\hline Flying shear & Normal & 40045 & 31889 \\
\hline
\end{tabular}

\subsection{Perhitungan Reliabilitas dan Laju Kerusakan}

Perhitungan reliabilitas dan laju kerusakan digunakan untuk mengetahui fungsi kehandalan dari masingmasing mesin secara sistematis sekaligus menggambarkan fungsi laju kerusakannya, tersaji pada Tabel 7.

Tabel 7. Perhitungan Reliabilitas dan Laju Kerusakan Mesin Uncoiler

\begin{tabular}{|c|c|c|c|c|c|c|}
\hline $\mathbf{T i}$ & B & $\theta$ (menit) & $R(t)$ & $h(t)$ & $\mathbf{f}(\mathbf{t})$ & $\mathbf{F}(\mathbf{t})$ \\
\hline 50 & \multirow{10}{*}{0,513} & \multirow{10}{*}{7458,968} & 0,926 & $1,084, \mathrm{E}-03$ & 1,004,E-03 & 0,074 \\
\hline 115 & & & 0,604 & 7,224,E-04 & $3,133, \mathrm{E}-05$ & 0,396 \\
\hline 120 & & & 0,604 & 7,075,E-04 & 3,183,E-05 & 0,396 \\
\hline 180 & & & 0,605 & 5,807,E-04 & 3,673,E-05 & 0,395 \\
\hline 180 & & & 0,605 & 5,807,E-04 & $3,673, \mathrm{E}-05$ & 0,395 \\
\hline 255 & & & 0,607 & 4,901,E-04 & $4,123, \mathrm{E}-05$ & 0,393 \\
\hline 300 & & & 0,608 & 4,528,E-04 & 4,341,E-05 & 0,392 \\
\hline 325 & & & 0,609 & 4,355,E-04 & 4,451,E-05 & 0,391 \\
\hline 366 & & & 0,610 & $4,110, \mathrm{E}-04$ & 4,617,E-05 & 0,390 \\
\hline 380 & & & 0,610 & 4,036,E-04 & 4,670,E-05 & 0,390 \\
\hline
\end{tabular}

\subsection{Perhitungan MTBF (Mean Time Between Failure)}

Mean time between failure adalah rata-rata waktu antar kerusakan dari mesin. Perhitungan ini dilakukan untuk mengetahui nilai MTBF dari setiap mesin.

Berikut ini adalah contoh perhitungan MTBF untuk mesin uncoiler :

$$
\begin{array}{ll}
\text { MTBF } & =\theta \Gamma(\mathrm{x}) \\
\mathrm{X} & =1+\frac{1}{\beta} \\
& =1+\frac{1}{0,513}=2,949 \\
\text { MTBF } & =\theta \Gamma(2,949)
\end{array}
$$

Nilai fungsi gamma $\Gamma(\mathrm{x})$ dengan $\mathrm{x}=2,949$ dapat diketahui nilainya adalah sebagai berikut :

$$
\begin{aligned}
\Gamma(2,949) & =1,910 \\
\operatorname{MTBF} & =\theta \Gamma(\mathrm{x}) \\
& =7458,968 \times 1,910 \\
& =14.246 \text { menit }
\end{aligned}
$$


Tabel 8. Rekapitulasi MTBF Mesin dengan Distribusi

\begin{tabular}{lcc}
\hline \multirow{2}{*}{\multicolumn{1}{c}{ Mesin }} & \multicolumn{2}{c}{ Nilai MTBF } \\
\cline { 2 - 3 } & Menit & Hari \\
\hline Looper & 42.832 & 30 \\
Pinch roll & 220.813 & 154 \\
Shear back pinch roll & 203.176 & 142 \\
Trimmer & 22.531 & 16 \\
Uncoiler & 14.246 & 10 \\
Welder & 13.116 & 10 \\
Stand\#1 & 4.981 & 4 \\
Stand\#2 & 15.098 & 11 \\
Stand\#3 & 16.490 & 12 \\
Stand\#4 & 13.861 & 10 \\
Stand\#5 & 2.720 & 2 \\
Recoiler & 5.605 & 4 \\
Flying shear & 40.045 & 28 \\
\hline
\end{tabular}

\subsection{Reliabilitas Mesin pada Unit Produksi CTCM Kondisi Eksisting}

Setelah didapatkan nilai MTBF pada setiap mesin, berikutnya dihitung nilai reliabilitas mesin, tersaji pada Tabel 9.

Tabel 9. Perhitungan Reliabilitas Mesin dengan Distribusi

\begin{tabular}{lcccc}
\hline \multirow{2}{*}{ Mesin } & \multicolumn{2}{c}{ Downtime } & & \\
\cline { 2 - 3 } & Menit & Hari & & $\begin{array}{c}\text { \% } \\
\text { Rooper }\end{array}$ \\
\cline { 2 - 3 } Pinch roll & 42.832 & 30 & 0,2503 & 25,03 \\
& 220.813 & 154 & 0,1760 & 17,60 \\
Shear back & & & & \\
pinch roll & 203.176 & 142 & 0,1943 & 19,43 \\
Trimmer & 22.531 & 16 & 0,2780 & 27,80 \\
Uncoiler & 14.246 & 10 & 0,2482 & 24,82 \\
Welder & 13.116 & 10 & 0,3091 & 30,91 \\
Stand\#1 & 4.981 & 4 & 0,3175 & 31,75 \\
Stand\#2 & 15.098 & 11 & 0,3131 & 31,31 \\
Stand\#3 & 16.490 & 12 & 0,3030 & 30,30 \\
Stand\#4 & 13.861 & 10 & 0,2930 & 29,30 \\
Stand\#5 & 2.720 & 2 & 0,3155 & 31,55 \\
Recoiler & 5.605 & 4 & 0,2976 & 29,76 \\
Flying & 40.045 & 28 & 0,6011 & 60,11 \\
shear & & & &
\end{tabular}

\subsection{Reliability Block Diagram}

Reliability block diagram digunakan untuk mengetahui kehandalan sistem dengan mengacu kepada jaringan kehandalan unit produksi CTCM (Larasati, 2017).

R.total (Rt)

$\mathrm{Rt} \quad=\mathrm{Rp} 1 \times \mathrm{Rs} 4 \times \mathrm{Rs} 5$

$$
\begin{aligned}
& =71,58 \% \times 60,28 \% \times 77,89 \% \\
& =33,61 \%
\end{aligned}
$$

Artinya rata-rata peluang unit produksi CTCM untuk dapat beroperasi sebesar $33,61 \%$ pada eksisting. 


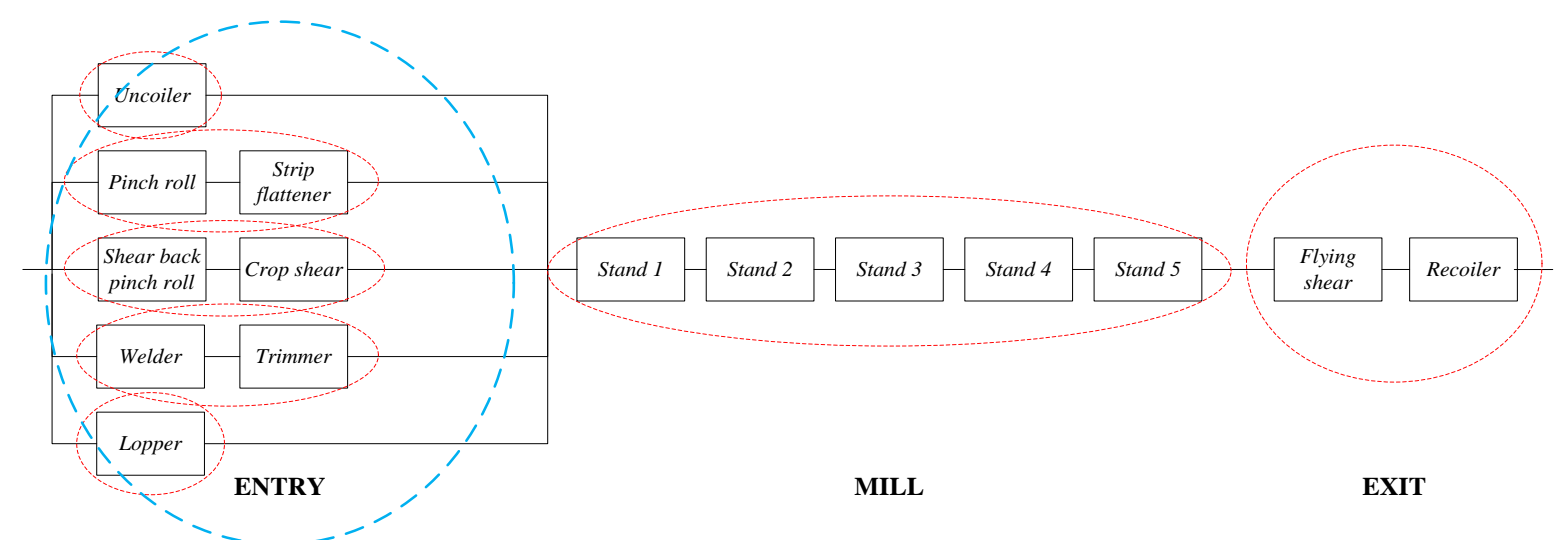

Gambar 4. Block Diagram Unit Produksi CTCM

Rata-rata peluang unit produksi CTCM untuk dapat beroperasi sebesar 33,61\% pada kondisi nyata. Hal tersebut disebabkan karena mesin yang ada sudah terlalu tua dengan umur pakai lebih dari 40 tahun. Pada periode bulan Januari hingga Oktober unit produksi CTCM mampu memproduksi sebanyak 501.172 ton dari kapasitas produksi 650.000 ton/tahun. Setiap mesin memilik frekuensi kerusakan yang berbeda-beda. Sehingga waktu usulan perawatan untuk mesin dihitung berdasarkan jumlah produksi yang dihasilkan per kerusakan yang dibandingkan dengan kapasitas produksi dari perusahan per satuan menit sehingga didapat waktu perawatan yang sesuai dengan kemampuan kinerja setiap mesin.

Berikut ini adalah perhitungan preventive maintenance setiap mesin di unit produksi CTCM, tersaji pada Tabel 10.

Tabel 10. Perhitungan Preventive Maintenance

\begin{tabular}{|c|c|c|c|c|c|}
\hline Mesin & $\begin{array}{c}\text { Frekuensi } \\
\text { Kerusakan }\end{array}$ & $\begin{array}{c}\text { Jumlah } \\
\text { Produksi } \\
\text { (ton) } \\
\end{array}$ & $\begin{array}{c}\text { Produksi } \\
\text { (ton) } \\
\text { /kerusakan } \\
\end{array}$ & $\begin{array}{c}\text { Kapasitas } \\
\text { Produksi } \\
\text { (ton)/menit }\end{array}$ & $\begin{array}{c}\text { Preventive } \\
\text { Maintenance } \\
\text { (menit) }\end{array}$ \\
\hline Crop shear & 2 & & 250586,00 & & 19985,20 \\
\hline Looper & 13 & & 38551,69 & & 3074,65 \\
\hline Pinch roll & 6 & & 83528,67 & & 6661,73 \\
\hline $\begin{array}{l}\text { Shear back } \\
\text { pinch roll }\end{array}$ & 5 & & 100234,40 & & 7994,08 \\
\hline $\begin{array}{l}\text { Strip } \\
\text { flattener }\end{array}$ & 2 & & 250586,00 & & 19985,20 \\
\hline Trimmer & 12 & & 41764,33 & & 3330,87 \\
\hline Uncoiler & 32 & 501172 & 15661,63 & 1254 & 1249,07 \\
\hline Welder & 36 & $5011 / 2$ & 13921,44 & 12,54 & 1110,29 \\
\hline Stand\#1 & 82 & & 6111,85 & & 487,44 \\
\hline Stand\#2 & 55 & & 9112,22 & & 726,73 \\
\hline Stand\#3 & 34 & & 14740,35 & & 1175,60 \\
\hline Stand\#4 & 43 & & 11655,16 & & 929,54 \\
\hline Stand\#5 & 140 & & 3579,80 & & 285,50 \\
\hline Recoiler & 78 & & 6425,28 & & 512,44 \\
\hline $\begin{array}{l}\text { Flying } \\
\text { shear }\end{array}$ & 3 & & 167057,33 & & 13323,46 \\
\hline
\end{tabular}

Tabel 11. Perhitungan Reliabilitas Mesin Usulan

\begin{tabular}{|c|c|c|c|c|c|c|c|}
\hline Mesin & $\boldsymbol{\beta}$ & $\boldsymbol{\Theta}$ & $\boldsymbol{\mu}$ & $\sigma$ & $\Lambda$ & $\begin{array}{c}\mathbf{R} \\
\text { (Preventive } \\
\text { Maintenance) }\end{array}$ & $\begin{array}{c}\% \\
\text { Kehandalan }\end{array}$ \\
\hline $\begin{array}{l}\text { Crop } \\
\text { shear }\end{array}$ & & & & & $\begin{array}{c}3,835 \mathrm{E}- \\
06\end{array}$ & 0,9262 & 92,62 \\
\hline Looper & 0,519 & 22850,961 & & & & 0,7023 & 70,23 \\
\hline $\begin{array}{l}\text { Pinch } \\
\text { roll } \\
\text { Shear }\end{array}$ & 0,357 & 47009,382 & & & & 0,6079 & 60,79 \\
\hline $\begin{array}{l}\text { back } \\
\text { pinch roll }\end{array}$ & 0,392 & 57604,040 & & & & 0,6304 & 63,04 \\
\hline $\begin{array}{l}\text { Strip } \\
\text { flattener }\end{array}$ & & & & & $\begin{array}{c}1,445 \mathrm{E}- \\
06\end{array}$ & 0,9715 & 97,15 \\
\hline Trimmer & 0,598 & 14910,225 & & & & 0,6649 & 66,49 \\
\hline
\end{tabular}




\begin{tabular}{lcc|cccc} 
Uncoiler & 0,513 & 7458,968 & & & 0,6704 & 67,04 \\
Welder & 0,706 & 10447,718 & & & 0,8144 & 81,44 \\
Stand\#1 & 0,740 & 4136,809 & & & 0,8143 & 81,43 \\
Stand\#2 & 0,722 & 12276,830 & & & 0,8783 & 87,83 \\
Stand\#3 & 0,683 & 12717,570 & & & 0,8215 & 82,15 \\
Stand\#4 & 0,647 & 10097,539 & & & 0,8077 & 80,77 \\
Stand\#5 & 0,732 & 2237,175 & & & 0,8012 & 80,12 \\
Recoiler & 0,663 & 4194,740 & & & 0,7805 & 78,05 \\
Flying & & & & & & 71,92 \\
shear & & & & & & \\
\hline
\end{tabular}

Dari perhitungan tersebut didapatkan bahwa nilai preventive maintenance pada mesin uncoiler adalah 19.985,2 menit, nilai reliabilitas mesin uncoiler adalah 0,6704 dan persentase kehandalan sebesar $67,04 \%$. Berdasarkan preventive maintenance, rata-rata peluang unit produksi CTCM untuk dapat beroperasi sebesar 21,18\% dengan kondisi penerapan periode perawatan usulan.

\subsection{Availability}

Perhitungan availability ini dilakukan untuk menggambarkan pemanfaatan waktu yang tersedia untuk kegiatan operasi mesin (Betrianis dkk, 2005). Perhitungan avaibility awal (corrective) dan avaibility usulan (preventive) dilakukan untuk mengetahui apakah penerapan preventive maintenance mengurangi avaibility mesin saat beroperasi.

Diketahui loading time adalah $(304 \times 24 \times 60$ menit $=437760$ menit $)$, berikut perhitungan avaibility setiap mesin pada unit produksi CTCM, tersaji pada Tabel 12.

Tabel 12. Rekapitulasi Availability Mesin

\begin{tabular}{lcc}
\hline \multirow{2}{*}{ Mesin } & \multicolumn{2}{c}{ avaibility time (\%) } \\
\cline { 2 - 3 } & corrective & preventive \\
\hline Crop shear & 78,13 & 95,43 \\
Looper & 90,22 & 99,30 \\
Pinch roll & 49,56 & 98,48 \\
Shear back pinch roll & 53,59 & 98,17 \\
Strip flattener & 61,85 & 95,43 \\
Trimmer & 94,85 & 99,24 \\
Uncoiler & 96,75 & 99,71 \\
Welder & 97,00 & 99,75 \\
Stand\#1 & 98,86 & 99,89 \\
Stand\#2 & 96,55 & 99,83 \\
Stand\#3 & 96,23 & 99,73 \\
Stand\#4 & 96,83 & 99,79 \\
Stand\#5 & 99,38 & 99,93 \\
Recoiler & 98,72 & 99,88 \\
Flying shear & 90,85 & 96,96 \\
\hline
\end{tabular}

\section{Simpulan}

Berdasarkan hasil perhitungan semakin kecil nilai MTBF dari suatu mesin, frekuensi kerusakan semakin banyak pada mesin tersebut. Semakin besar nilai reliabilitas mesin semakin besar nilai availabilitasnya. Semakin banyak frekuensi kerusakan yang dialami mesin maka diperlukan perawatan mesin yang rutin. Nilai reliabilitas setiap mesin yang meningkat mempengaruhi persentase reliabiltas sistem. Dibandingkan dengan corrective maintenance, jadwal preventive maintenance yang diusulkan meningkatkan nilai availabilitas mesin sebesar $21.18 \%$.

\section{Daftar Pustaka}

Betrianis dan Robby Suhendra. 2005. Pengukuran Nilai Overall Equipment Effectiveness Sebagai Dasar Usaha Perbaikan Proses Manufaktur Pada Lini Produksi. Jurnal Teknik Industri Vol 7 No 2. 
Ebeling, C.E. 1997. An Introduction to Reliability and Maintainability Engineering. New York : The McGraw.

Kudin, A. W. 2012. Analisa Penjadwalan Maintenance Komponen Listrik Pada Unit Stand 3 PT. XYZ Dengan Reliability Block Diagram. (Skripsi). Jurusan Teknik Industri, Fakultas Teknik, Universitas Sultan Ageng Tirtayasa.

Kulsum, Febianti, E. dan Supriatna, H.I . 2018. Usulan Waktu Preventive Maintenance Untuk Menurunkan Downtime Mesin Paper Mill 1 dengan Reliability Block Diagram. Prodising Seminar Nasioanl Sains dan Teknologi. Fakultas Teknik Universitas Muhammadyah Jakarta.

Larasati, S. 2017. Usulan Waktu Preventive Maintenance Untuk Menurunkan Downtime Mesin Crane 0746 Dengan Reliability Block Diagram di PT XYZ. (Skripsi). Jurusan Teknik Industri Universitas Sultan Ageng Tirtayasa

Nuhman. 2016. Usulan Penentuan Kebutuhan Spare Parts Mesin Compressor Berdasarkan Reliability. (Skripsi). Jurusan Teknik Industri Universitas Sultan Ageng Tirtayasa.

Priyanta, Dwi. 2000. Keandalan dan Perawatan. Surabaya : Institut Teknologi Sepuluh Nopember.

Saputro, D. S. 2013. Usulan Penjadwalan Perawatan Dengan Mempertimbangkan Reliability Blok Diagram Pada Mesin SPM 2000 PT Z. (Skripsi). Jurusan Teknik Industri, Fakultas Teknik, Universitas Sultan Ageng Tirtayasa 